\title{
細胞診陰性胸水を有した原発性肺癌に対する胸腔鏡検査 気管支内視鏡を用いて
}

\author{
Thoracoscopy by the Flexible Bronchoscope for Lung Cancer \\ with Cytology-negative Pleural Effusion
}

瀬戸貴司・千場 博・深井祐治・稲吉 $\quad$ 厚* 蔵野良一**

要旨：〔目的〕原発性肺癌の胸水症例で, 胸腔穿刺胸水検查にて細胞診陰性であった症例を局 所麻酔下に気管支内視鏡を用いた胸腔鏡検查を行い検討した。〔対象〕原発性肺癌の診断 が確定した症例で, 画像診断上, 腫瘍の胸壁浸潤が認められず, 胸水が滲出性で, ADA が低值 (40IU/1以下), リンパ球が優位, 細胞診が陰性であった19例(17例が肺癌の担癌症 例で 2 例が肺癌切除術後症例) を対象とした。〔結果〕担癌例の 11 例, 術後例の 1 例に病 理組織学的に肺癌浸潤の診断が得られた。非特異的炎症が 6 例に認められ，ドレナージ 以外の特別な治療なしに胸水の再貯留は認められなかった.〔考察】胸水中の悪性細胞が 㓌性であった症例には，高率に非悪性胸水症例が含まれていた，気管支内視鏡を用いた 胸腔鏡検査は極めて簡単な操作で, 主たる合併症なしに施行することが可能で, 臨床病 期診断，治療方針決定に重要な情報を得ることが可能になると考えられた.

〔肺癌 $37(1): 41 \sim 45$, 1997〕

Key words: Thoracoscopy, Flexible bronchoscope, Lung cancer

Malignant pleural effusion

はじめに

原発性肺癌で胸水貯留を来した症例は, 胸水 中の悪性細胞が陰性であっても, 明確に肺癌以 外の疾患が証明されない場合は肺癌取扱い規約11 でT4として扱われ，無気肺の合併がない場合の 多くは手術適応外と判断される.今回これらの いわゆるT4胸水貯留を来した原発性肺癌で 2 回 以上の胸腔穿刺胸水診断にて悪性細胞が㓌性で あった症例に気管支内視鏡を用いた胸腔鏡検査 を施行し, 臨床的意義と検査の有用性を検討し た。

熊本地域医療センタ一呼吸器科

$\begin{array}{lll}* & \text { 同 } & \text { 外科 } \\ * * & \text { 同 } & \text { 病理 }\end{array}$

対 象:(Table 1)

平成元年 1 月から平成 8 年 4 月までの期間に 当センターを受診し, 細胞診または組織診にて 原発性肺癌と診断された765例中, 来院時胸水貯 留肺癌は85例であった。これらの胸水が滲出性

Table 1. Patients characteristics.

\begin{tabular}{ll}
\hline No. of patients & 19 \\
Sex M/F & $13 / 6$ \\
Mean Age (range) & $76(58-91)$ \\
Cancer patients & 17 \\
Resected patients & 2 \\
Histological type & \\
$\quad$ Adenocarcinoma & 15 \\
$\quad$ Small cell carcinoma & 3 \\
Large cell carcinoma & 1 \\
\hline
\end{tabular}


で, adenosin deaminase (ADA) が40IU/1以下， リンパ球が優位, 2 回以上のパパニコロ染色細胞 診で悪性細胞㓌性でかつ, 画像診断上, 胸膜へ の腫瘍浸潤が認められなかった19例を対象とし た.19例のうち17例が組織学的に確定診断され た肺癌担癌症例で, 2 例が肺癌切除術後症例で あった。 小細胞肺癌 3 例, 非小細胞肺癌 16 例 (腺 癌 15 例, 大細胞癌 1 例) で, 男性 13 人, 女性 6 人, 平均年齢は76才であった。

\section{方 法}

手技は以前の報告 ${ }^{2)} の こ ゙ と く$ 行ったが, 検查前 にトラカールカテーテルを挿入し，十分胸水の 排液を行った。前処置として硫酸ペンタゾシン 15mgを筋注した。酸素マスクにて 3 ６/分の 酸素投与を行い, 胸水排液用カテーテルより純 酸素300～500mlを挿気，人工気胸状態とした。 局所麻酔下, 2 箇所に約 $5 \sim 6 \mathrm{~cm}$ 間隔で皮切を 加之鈍的に胸腔穿通孔を形成した. 胸腔穿刺孔 より直接, 観察用として滅菌したオリンパス社製 BF6C-10またはビデオ気管支内視鏡BF Type200 , 生検用として同社製BFXT-10を同時に挿入 し，観察及び生検を施行した。検查中はパルス オキシメーター及び心電図モニターで監視を行 つた。観察及び生検終了後はトブラマイシン $60 \mathrm{mg}$ を注入し，約 1 時間カテーテルより持続吸引を 行い抜去した。検查後は数日間, 経口抗生剤を 投与したが検査後の膿胸等の合併症は認められ なかった。

気管支内視鏡の滅菌は塩化ベンゼトニウム液, 及び流水での洗浄後, $2 \%$ グルタールアルデヒ ド液に約 1 時間浸漬し，エチレンオキサイドガ ス滅菌を行った。

\section{結 果 : (Table 2)}

原発性肺癌担癌例17例中14例に壁側胸膜に隆 起性病変が認められた。 その内訳は 3 例が単発 性のポリープ状隆起で, 6 例が複数のポリープ, 2 例がポリポイド様病変を呈した。また扁平隆 起 2 例，結節隆起 1 例が認められた。 3 例に発 赤や血管怒張所見が認められた。組織学的検査 では発赤所見を呈した 3 例全例及び扁平隆起,
単発性ポリープ状病変を呈した各 1 例に慢性炎 症細胞浸潤が認められ, 計 5 例が非特異的炎症 と診断された。結節性隆起を呈した症例は病理 組織学的検查では好酸球性膿瘍とされ, 病歴と 血清抗体学的検查から肺吸虫症と診断された。 その他の11例は生検組織学的検查にて悪性細胞 浸潤が証明された。胸腔鏡検査を施行すること により,臨床病期IIIB期と診断された10例中の 4 例(症例 3.7 .12 .14 )が非悪性胸水( T4胸水では ない)と診断され，切除可能と判断された。

また，組織学的悪性細胞浸潤が認められた11例 中, 1 例 (症例 5 ) が胸壁浸潤病変が微小単発で あったことから，切除可能と判断された。この ことから, 担癌症例 17 例中 5 例に手術適応症例 が含まれていると判断された。

術後症例 2 例は, 胸膜療着のため観察視野が 狭く，観察が困難であったが，1例が発赤所見 を呈し生検組織診断上，非特異的炎症， 1 例が ポリポイド样病変からの生検で肺癌浸潤の診断 が得られた。

全19症例のうち，非特異的炎症と診断された 6 例はドレナージ以外の特別な治療なしに経過 観察がなされたが, 胸水の再貯留は認められな かった。

\section{考 察}

原発性肺癌で胸水貯留を来した症例は肺癌取 扱い規約1)で肺癌と関係のある胸水の多くは腫 瘍によるものである。しかし中には何回にも及 ぶ細胞診検查にても㓌性の例もある。非血性で 非滲出性である。こういう場合は胸水が腫瘍と 関係ないことを胸水の症状を臨床判断で決めそ の病期から除外し，T1，T2またはT3とする.」 と記載され，無気肺の合併等がない場合の滲出 性胸水は, 細胞診検查で㓌性であっても 44 胸水 (悪性胸水)として扱われている，今回これらの 細胞診㓌性 $\mathrm{T} 4$ 胸水を観察用及び生検用気管支内

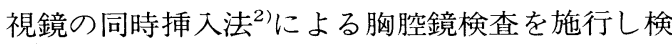
討した。胸腔鏡検查を施行することにより，原 発性肺癌担癌症例中, 何らかの限局性隆起性病

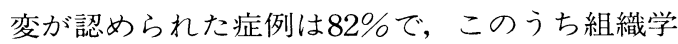
的に悪性腫瘍浸潤が証明された症例は65\%であ 
Table 2. Findings of pleural cavity and histological diagnosis by thoracoscopy of lung cancer patients with cytology-negative pleural effusion. Histological diagnosis of metastasis in the pleural cavity were made in 11 cases of lung cancer patients and 1 of the resected patients. No. 3. 7 . 12. and 14 cases had inflammatory effusion and were found to have operable disease.

\begin{tabular}{|c|c|c|c|c|c|c|c|c|c|}
\hline \multicolumn{2}{|c|}{ Age } & Sex & \multirow[t]{2}{*}{ Histology } & \multicolumn{2}{|c|}{$\begin{array}{l}\text { TNM Stage } \rightarrow \\
\text { befor thoracoscopy }\end{array}$} & \multicolumn{2}{|c|}{$\begin{array}{l}\text { T Stage } \\
\text { er thoracoscopy }\end{array}$} & \multirow[t]{2}{*}{ findings } & \multirow[t]{2}{*}{ Histology } \\
\hline \multicolumn{7}{|c|}{ Lung cancer patients } & & & \\
\hline 1 & 62 & $\mathrm{M}$ & $\operatorname{Ad}($ poor $)$ & T4N2M1 & IV & $\mathrm{T} 4$ & IV & small polyps & $\operatorname{Ad}($ poor $)$ \\
\hline 2 & 59 & $\mathrm{M}$ & $\mathrm{Sm}$ & T4N2M1 & IV & $\mathrm{T} 4$ & IV & elevated lesion & $\mathrm{Sq}$ (well) \\
\hline 3 & 88 & $\mathrm{M}$ & $\operatorname{Ad}(\bmod )$ & T4N0M0 & IIIB & $\mathrm{T} 2$ & $\mathrm{I}$ & polyp & inflammation \\
\hline 4 & 82 & M & $\operatorname{Ad}(\bmod )$ & T4N2M1 & IV & $\mathrm{T} 2$ & IV & nodule & eosinophilic abscess \\
\hline 5 & 58 & $\mathrm{M}$ & $\operatorname{Ad}($ poor $)$ & T4N2M0 & IIIB & $\mathrm{T} 4$ & IIIB & small polyps & $\operatorname{Ad}($ poor $)$ \\
\hline 6 & 80 & $\mathrm{M}$ & $\operatorname{Ad}(\bmod )$ & T4N2M1 & IV & $\mathrm{T} 4$ & IV & small polyps & $\operatorname{Ad}($ poor $)$ \\
\hline 7 & 84 & $\mathrm{M}$ & $\mathrm{Sm}$ & T4N1M0 & IIIB & $\mathrm{T} 2$ & II & redden & inflammation \\
\hline 8 & 87 & M & $\operatorname{Ad}(\bmod )$ & T4N0M0 & IIIB & $\mathrm{T} 4$ & IIIB & polypoid & Ad(mod-poor) \\
\hline 9 & 74 & $\mathrm{M}$ & $\mathrm{Sm}$ & T4N3M1 & IV & $\mathrm{T} 2$ & IV & redden & inflammation \\
\hline 10 & 73 & $\mathrm{~F}$ & $\operatorname{Ad}($ poor $)$ & T4N2M1 & IV & $\mathrm{T} 4$ & IV & small polyp & $\operatorname{Ad}($ poor $)$ \\
\hline 11 & 91 & $\mathrm{M}$ & $\operatorname{Ad}(\bmod )$ & T4N3M0 & IIIB & $\mathrm{T} 4$ & IIIB & small polyp & Ad(mod-poor) \\
\hline 12 & 82 & $\mathrm{~F}$ & $\operatorname{Ad}($ poor $)$ & $\mathrm{T} 4 \mathrm{~N} 2 \mathrm{M} 0$ & IIIB & $\mathrm{T} 2$ & III A & elevated lesion & inflammation \\
\hline 13 & 73 & $\mathrm{M}$ & $\operatorname{Ad}(\bmod )$ & T4N3M0 & IIIB & $\mathrm{T} 4$ & IIIB & small polyps & $\operatorname{Ad}($ poor $)$ \\
\hline 14 & 86 & $\mathrm{~F}$ & $\operatorname{Ad}($ poor $)$ & T4N1M0 & IIIB & $\mathrm{T} 2$ & II & redden & inflammation \\
\hline 15 & 69 & $\mathrm{~F}$ & $\operatorname{Ad}(\bmod )$ & T4N3M1 & IV & $\mathrm{T} 4$ & IV & polyps & $\operatorname{Ad}(\bmod -$ poor $)$ \\
\hline 16 & 77 & $\mathrm{M}$ & $\operatorname{Ad}(\bmod )$ & T4N2M0 & IIIB & $\mathrm{T} 4$ & IIIB & polyps & $\operatorname{Ad}(\bmod )$ \\
\hline 17 & 69 & $\mathrm{~F}$ & $\operatorname{Ad}($ poor $)$ & T4N1M0 & IIIB & $\mathrm{T} 4$ & IIIB & polypoid & $\operatorname{Ad}($ poor $)$ \\
\hline \multicolumn{10}{|c|}{ Resected patients } \\
\hline 18 & 63 & $\mathrm{M}$ & Ad(well) & $\mathrm{p}-\mathrm{T} 2 \mathrm{~N} 2 \mathrm{M}$ & & & & redden & inflammation \\
\hline 19 & 77 & $\mathrm{~F}$ & $\mathrm{La}$ & $\mathrm{p}-\mathrm{T} 2 \mathrm{~N} 1 \mathrm{M}$ & & & & polypoid & $\mathrm{La}$ \\
\hline
\end{tabular}

Ad : adenocarcinoma Sm : small cell carcinoma La : large cell carcinoma Sq : squamous cell carcinoma poor : poory differentiated $\bmod :$ moderate differentiated well : differentiated

った。これに対し，びまん性に隆起性病変が認 められた症例は, 切除術後例の 1 例のみであり, 盲目的な胸膜生検法では診断の確定が極めて困 難であると考えられた。隆起性病変が認められ なかった症例は全例, 発赤, 血管怒張所見を呈 しており, 全体の35\%が非悪性胸水(炎症性胸水) と診断された。非特異的慢性炎症と診断された 症例は胸腔ドレナージのみで胸水の再貯留は認 められず，胸腔鏡検査を施行することにより， 不必要な抗癌化学療法剂による胸膜癒着術 ${ }^{3)}$ を回 避することが可能であると考えられた。

実際には高齢であること，本人及び家族の希 望により手術を施行し得た症例はなかったが, 臨床病期 IIIB期 (今後は IV A期に分類され, 手術 不適応症例とされる可能性もある)と診断された 症例の $40 \%$, 壁側胸膜転移巣が微小単発であ った症例を含めると50\%に手術適応症例が含ま
れていた。児玉等の報告 ${ }^{4)}$ では, T4胸水 IIIB期症 例で, N0, N1症例は積極的に切除を行うことで, 良好な経過が得られるとされている。また，胸

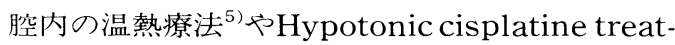
ment $t^{6)}$ 等の胸膜病変への治療を切除術に加之行 うことにより，手術成績の向上が得られるとさ れている。しかも非小細胞肺癌は現在，外科切 除以外には十分な治療効果が得られていない. 胸水中に悪性細胞が証明されなかった症例だけ ではなく，胸水中に悪性細胞浸潤が認められた 症例でも，比較的に軽度な胸水貯留症例や胸水 中の悪性細胞が少ない症例には，積極的に胸腔 鏡検査を行い，手術適応を十分に検討する必要 があると考えられた。また，今回の検討には中 心型肺癌の無気肺に伴う胸水貯留症例が含まれ ていないが, これらの症例の手術適応を検討す るうえで，胸腔鏡検査は必須であると考えられ 
る。

胸腔鏡検查の肺癌病期診断での有用性は古く から報告7)されているが, 実際には呼吸器内科医 が硬性鏡の扱いや全身麻酔に慣れていないこと が理由で，外科医によって行われている場合が 多い。また，我々も含め一部の施設で呼吸器内 科医がその取扱に最も慣れている気管支内視鏡 を用いて胸腔内観察を行うことが試みられてい $3^{8), 9)}$ が, 観察視野が狭い等の理由でポピュラー な検査法とはなっていない。しかし，観察視野 は観察用ビデオ気管支内視鏡を用いることによ ク，極めて良好な胸腔内の観察が可能 (Fig. 1)で, また，同時に複数の医師による観察が可能であ る。観察用気管支内視鏡は大型の生検鉗子が使 用できなく，組織採取が十分とは言之ない，生 検用気管支内視は大型の生検鉗子の使用が可能 であるが, 視野が狭いため, 単独で病変に達卞 ることが困難である。しかし，観察用気管支内 視鏡と生検用気管支内視鏡を同時に挿大するこ とにより，十分な生検組織標本を得ることが可 能である.今回の検討で非特異的炎症と診断さ れた症例をドレナージのみで経過観察を行った が, 胸水が再貯留した症例は認められておらず,
Fig. 1. Thoracoscopic findings of pleural cavity by flexible video bronchoscopy (BF Type-200) of lung cancer patients with cytology-negative effusion. Small polyps were seen on the parietal pleura. Biopsy specimen revealed metastasis from lung cancer (patient No. 5).

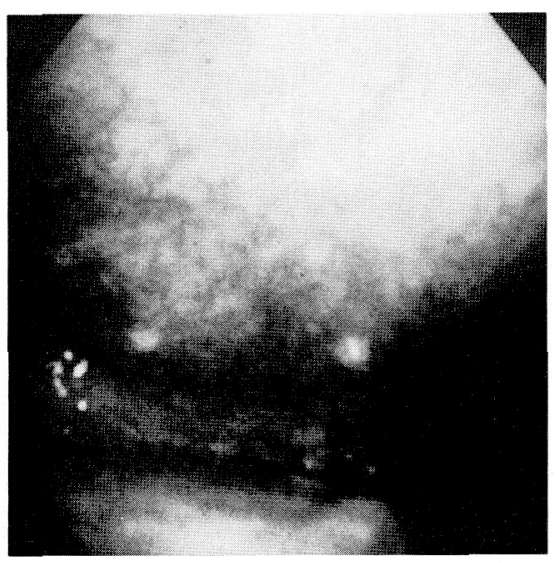

検査の精度として十分であると考えられた。術 中術後の合併症は認如れず，全検查時間も平 均45分程度と短く, 呼吸器内科医にとって極め て簡便な検查で極めて有用な情報が得られる検 查法と考えられた。

\section{文 献}

1) 成毛韶夫：TNM分類，肺癌取扱い規約 編集， 日本肺癌学会, 金原出版, 東京, 23-30頁, 1995.

2) 瀬戸貴司，千場 博，深井祐治，他：観察用及 び生検用気管支内視鏡同時挿入による胸腔鏡検 查一原因不明胸水 50 例の検討一, 日胸疾会誌 34 : 947-952, 1996.

3) Steven M, Keller MD : Current and Future Therapy for Malignant Pleural effusion. Chest Jun 103 : 63S-67S, 1993.

4) Kodama K, Doi O, Higashiyama M, et al : Long-term Results of Postoperative Intrathoracic Chemotherapy for Lung Cancer with Pleural Dissemination. Cancer Jul 15 : 426-431.

5) Matsuzaki Y, Shibata K, Yoshioka M, et al : Intrapleural Perfusion Hyperthermo-chemotherapy for Malignant Pleural Dissemination and effusion. Ann Thrac Surg Jan 59 : 127131, 1995.

6) Ichinose $Y$, Hara N, Ohta M, et al : Hypotonic Cisplatin Treatment for Carcinomatous Pleuritis Found at Thoracotomy in Patients with Lung Cancer. J Thorac Cardiovasc Surg 105 : 1041-1046, 1993.

7) Naruke T, Asamura $\mathrm{H}$, Kondo $\mathrm{H}$, et al : Thoracoscopy for Staging of Lung Cancer. Ann Thorac Surg Sep 56 : 661-663, 1993.

8) 千場 博, 梁井祐治, 中村博幸, 他: 気管支 アイバースコープの胸腔鏡としての応用. 気管 支 $14: 708-708,1992$.

9）戸野垓博，鈴木一，秋沢孝則，他：気管支鏡 を用いた胸腔内検査. 日胸疾会誌 $26: 936-941$, 1998. 


\title{
Thoracoscopy by the Flexible Bronchoscope for Lung Cancer with Cytology-negative Pleural Effusion
}

\author{
Takashi Seto, Hiroshi Semba, Yuji Fukai \\ Atsushi Inayoshi*, and Ryouichi Kurano**
}

Divisions of Respiratory Disease, Surgery*, and Pathology**,

Kumamoto Regional Medical Care Center

We performed thoracoscopy on lung cancer cases with cytology-negative pleural effusion (examinations for pleural effusion were done more than 2 times). Thoracoscopy was performed by flexible bronchoscopes under local anesthesia. Nineteen lung cancer patients with pleural effusion but without metastatic pleural tumor in chest CT were studied. Whose pleural effusion was exudative, lymphocyte dominant, had a low level of $\mathrm{ADA}$, and a negative study of malignant cells in cytological pleural effusion smears. Seventeen patients were untreated lung cancer patients and 2 had been received resection. Histological diagnosis of metastasis to pleural cavity were made in 11 of untreated lung cancer patients and in one of the resected patients. Of the 6 cases of non-spesific inflammation no accumulation of pleural effusion was observed after only drainage. Although there is the exception of non-hemorrhagic and non-exudative effusion, pleural effusion of lung cancer are treated as malignant effusion, even in the cases whose effusion are negative for malignant cells. Thoracoscopy by the flexible bronchoscope is a simple procedure without major side effects, using equipment which pulmonary physicians are most accustomed to. The examination enables us to make correct staging for lung cancer. 